\title{
FORMATION OF THE NEW ZEALAND COMMITTEE ON PESTICIDE RESISTANCE
}

\author{
G.S. ELLIOTT, C.H. WEARING* and D.M. SUCKLING\#
}

\author{
AGCARM, P.O. Box 27-283, Wellington \\ *Entomology Division, DSIR, Auckland \\ \#Entomology Division, DSIR, Christchurch
}

\section{SUMMARY}

The status of insecticide and fungicide resistance in New Zealand is briefly reviewed. Recent experiences with resistance and changes in pesticide use and development in New Zealand show the need to strengthen the organisation of pesticide resistance management. The formation, structure, objectives and functions of the New Zealand Committee on Pesticide Resistance are described.

\section{INTRODUCTION}

Chapman (1982) defined insecticide resistance as the develspment of an ability in a strain of an insect to tolerate doses of a toxicant which would prove lethal to the majority of individuals in a normal population of the same species. Fungicides resistance was defined by Delp and Dekker (1985) as "stable, inheritable adjustment by a fungus to a fungicide (toxicant)." Pests and pathogens, and more recently weeds, have demonstrated an impressive ability to develop resistance to the chemicals used for their control. Insects and mites are the biggest problem, with 447 resistant species reported by Georghiou (1986), including most major pests and 23 species already resistant to one of the most recent groups of insecticides, the synthetic pyrethroids. Georghiou (1986) also referred to at least 100 species of plant pathogens, 48 species of weeds, and two species of nematodes which have evolved resistance to pesticides. The increasing number of pest species with multiple resistance to a range of pesticides is a major concern. A few (e.g. Colorado potato beetle), have such a wide range of biochemical pathways to combat pesticides that they may now be "pre-adapted" for resistance to new chemicals. The high cost and increasing frequency of resistance has stimulated strong interest worldwide in finding ways to reduce its occurrence and impact (e.g. EPPO 1985; National Academy of Sciences 1986).

Chapman (1982) reported 17 species for which insecticide/acaricide resistance was either documented or suspected in New Zealand. Many of the reports referred to organochlorines (OC's), which have been withdrawn from use for reasons other than resistance. Apart from resistance in grass grub, housefly and green blowfly, all the cases were pests of horticulture. The impact of their resistance on horticultural production and exporting to date has been minor because alternative chemicals or other control methods have been available at reasonable cost. In the pastoral sector, insecticide use has declined and resistance is less likely to be a problem.

Hartill (1986) listed 15 species of plant pathogen with resistance to six fungicide groups in New Zealand. The only known case prior to 1970 was the resistance of Pyrenophora avenae to mercury-based fungicides. However, with the advent of systemic fungicides and those with a more specific mode of action, the number of resistant species has increased sharply. Hartill's (1986) list included a case of resistance to one of the latest groups of fungicides, the demethylation inhibitors (a group within the ergosterol biosynthesis inhibitors), and there are further examples of resistance to this group overseas (e.g. Thind et al 1986).

Although resistance in New Zealand has not had a dramatic impact on agricultural productivity, the cost has been high in terms of the loss of effective products. Ad hoc schemes of resistance management have been operated with some success for both fungicide and insecticide resistance. However, this approach needs now to be strengthened through a deliberate policy of pesticide resistance management.

Proc. 40th N.Z. Weed and Pest Control Conf. 


\section{THE NEED FOR PESTICIDE RESISTANCE MANAGEMENT IN NEW ZEALAND}

Important changes are taking place in pesticide use and development which could lead to greater problems with resistance and, especially, an increase in its economic impact in New Zealand.

The phenomenal growth of the horticultural sector (Bollard 1981) has meant that pesticide use is increasing rapidly and the area being treated is expanding. Both these factors increase the risk of resistance occurring in the future. Horticultural exports must meet the quarantine requirements of importing countries and increasingly complex controls on chemical residues in or on its products. The market to market variation in the acceptability of different residues and the frequent absence of residue tolerances for pests of novel or 'minor' crops are making New Zealand horticulture increasingly dependent on a narrow range of effective pesticides whose residues are acceptable in all our markets. Resistances to one of these available pesticides immediately threatens the export of the affected crop.

The New Zealand pesticide market is of very little consequence in the world market for pesticides. No chemical company can afford to develop pesticides specifically for the New Zealand market and arrange for acceptable residue tolerances overseas. It is critical therefore that New Zealand does not move ahead of world developments in pesticide resistance which could result in a need to use insecticides not yet widely registered. The research and development of new pesticides is increasingly expensive and New Zealand cannot rely on the continuing availability of new chemicals when resistance occurs. This is particularly true for fungicides where there is a severe shortage of new chemical groups.

The high cost of finding economically viable chemicals has also heightened the importance to the chemical industry of extending the period of return on this investment. A key to this is to prevent or delay resistance. To this end traditionally competitive companies are now collaborating in schemes throughout the world to coordinate pesticide use (e.g. Delp 1986; Jacḱson 1987).

Another important change for future resistance development is the increased specificity in the mode of action of new fungicides. Because of this, more cases of fungicide resistance can be anticipated unless measures are taken to avoid it. The demethylation inhibitors, such as triazoles and imidazoles, are a special concern. Not only can chemicals from this fungicide group be both specific and relatively broadspectrum in action, but some are also being developed as plant growth regulators, and lately even as herbicides. This brings the real risk of a crop being treated with the same group of compounds for three different purposes, thereby greatly compounding resistance selection pressure. The need to develop strategies to protect the useful life of this very valuable group of chemicals has become paramount.

Although resistant pests and pathogens in New Zealand are small in number, some are high risk species with a history of repeated resistance development. These include two-spotted mite (Tetranychus urticae), European red mite (Panonychus ulmi) (Chapman et al 1987), lightbrown apple moth (Epiphyas postvittana), botrytis (Botrytis cinerea), brown rot (Monilinia fructicola), and black spot of apples (Venturia inaequalis). Among these pests are some of major quarantine significance. If pest resistance results in the use of a new group of chemicals, the use of insecticide-resistant predatory mites in orchards (Wearing et al 1978) is threatened. Pesticides are essential components in most integrated pest management programmes and their withdrawl affects the whole crop ecosystem.

There is, therefore, a strong case for strengthening pesticide resistance management in New Zealand. While we still have an effective armoury of chemicals with different modes of action, we can learn from experiences overseas and take steps to avoid or at least delay the onset of resistance here. Recent cases of resistance, although subject to management programmes, confirm the need for a more structured approach. The catalyst that promoted action for better fungicide resistance management was the resistance of botrytis to dicarboximides. Industry/MAF/DSIR meetings resolved strategies, research needs, and future action to provide spray programmes effective in combatting the resistance. A programme to monitor resistant strains and an interim spray programme were agreed. All results were to be pooled. However, while a unified 
approach was achieved, the programme proved to be difficult to implement. Some growers were confused as to the crops affected by the resistance. Similar problems occurred in an attempt to manage resistance in cereal pathogens in 1986; agreed strategies were not well implemented and some conflicting recommendations were made.

With respect to insects, resistance to azinphos-methyl in lightbrown apple moth, which has occurred in a limited area of Nelson, stimulated a major resistance management programme (Suckling et al 1984) organised by an ad hoc committee of interested parties. Organisation of the programme, particularly during the initial critical stages, would have been greatly eased if supportive policy had been in place (Wearing 1986).

The recent policy models for resistance management in other countries (e.g. National Academy of Sciences 1986; Alcock and Drew 1986) can provide only a guide to initiatives in New Zealand. The special needs of New Zealand, which have been outlined, call for policy which will meet those needs.

\section{INITIATION OF RESISTANCE MANAGEMENT POLICY}

Pesticide resistance management is the planned use of pesticides in ways which will delay or avoid resistance. Like many simple concepts, it is complex in its application. Resistance management depends

i) on an understanding of the population genetics and mechanisms of resistance and its development,

ii) on reliable methods for the monitoring and detection of resistance,

iii) on the availability of strategies and tactics both to retain initial susceptibility to pesticides and to minimise the impact of resistance when it occurs, and

iv) on procedures for the implementation of programmes which will co-ordinate the activities of pesticide manufacturers, sellers and re-sellers, regulators, advisors, researchers, and end-users.

The remainder of this paper describes recent steps towards a more structured organisation of pesticide resistance management in New Zealand.

The Hawkes Bay Branch of the N.Z. Weed and Pest Control Society organised a seminar in 1982 which reviewed the status of resistance in New Zealand and the management measures which can be taken (Geelen and Esson 1982). This meeting was a valuable stimulus to initiatives on both insecticides and fungicides. The programme which was developed to combat resistance of lightbrown apple moth to azinphos-methyl (Suckling et al 1984) helped to define many of the important components for management of insecticide resistance. This case and the Australian experience with corn ear worn (Heliothis armigera) in cotton (Forrester and Cahill 1986) stimulated a joint CSIRO/DSIR workshop on insecticide resistance management in 1986 (Daly and Suckling 1986). This included information and discussion on policy for insecticide resistance management which formed the basis of proposals to establish a national committee on insecticide resistance management in New Zealand.

Recent programmes of fungicide resistance management for botrytis and cereal diseases have also provided valuable experience in the application of combined strategies and highlighted the need for the delivery of totally consistent information to the end-users. Participants in these programmes saw the benefit of replacing existing $a d$ hoc organisation with a more formal structure. It was felt that this could be achieved through a committee comprising representatives with authority to speak for their respective organisations (MAF, DSIR, and the chemical industry via AGCARM). AGCARM approached the Directors-General of DSIR and MAF, proposing that a meeting be held to further this aim and in March 1986 a steering committee was convened in Wellington.

The steering committee supported the concept of a national committee on pesticide resistance to bring together existing fungicide and insecticide management initiatives under one umbrella. Provisional objectives, functions, and guidelines for the operation of the one national committee were drafted and referred to participating organisations. It was agreed that the Universities should be invited to join the committee. Each "organisation" was then asked to nominate their representatives. 
THE NEW ZEALAND COMMITTEE ON PESTICIDE RESISTANCE (NZCPR)

The inaugural meeting of NZCPR was held in Wellington at the AGCARM offices on 23 April 1987. The Committee members are:

$\begin{array}{ll}\text { AGCARM: } & \text { G.S. Elliott (Convenor), M.S. Moore and C.I. } \\ & \text { Blincoe (Secretary) } \\ \text { DSIR: } & \text { P.J. Brook (Plant Diseases Division) and C.H. } \\ & \text { Wearing (Entomology Division) } \\ \text { MAFTECH } & \text { R.P. Pottinger (Ruakura Agricultural Research } \\ & \text { Centre) } \\ \text { LINCOLN COLLEGE } & \text { D.R. Penman (Entomology Department) } \\ \text { MASSEY UNIVERSITY } & \text { K.S. Milne (Department of Plant Health) }\end{array}$

The objectives of NZCPR were defined as follows:

i) To identify existing and potential resistance problems of importance.

ii) To establish Task Groups as appropriate.

iii) To communicate existing and new information to those involved in pesticide research, distribution and use.

iv) To recommend pesticide management procedures with the emphasis on prevention of resistance.

It was agreed that the principal functions of the NZCPR are:

i) To initiate and provide guidelines and coordinate the efforts of the Task Groups.

ii) To help the Task Groups communicate their conclusions.

iii) To publicise guidelines on procedures/definitions of practical resistance research.

iv) To provide technical counsel for Pesticide resistance courses and research studies.

v) To provide information flow between universities, private advisory services, producers (farmers, growers), chemical distributors, the agricultural chemical industry, the Government, central marketing authorities, and the NZCPR.

vi) To communicate the findings of the NZCPR to the Pesticides Board and other relevant authorities.

The Task Groups

NZCPR is similar to committees established overseas for improving the management of resistance problems. These committees have set up task groups or working parties to address resistance management for groups of chemicals (e.g. Delp 1986; Jackson 1987; Alcock and Drew 1986), groups of pests, such as mites (Alcock and Drew 1986), and areas of pesticide use, such as Public Health (Alcock and Drew 1986). Resistance management programmes usually operate in a particular crop/pest(s) association and aim for optimum use of groups of different chemicals to extend product life and delay resistance. As a first step, NZCPR has established two Task Groups, one for insecticides and the other for fungicides, with the following guidelines:

i) The convenor of each Task Group shall be a member of the NZCPR and shall report regularly to this Committee.

ii) Each Task Group should comprise technical representatives from AGCARM, MAF, DSIR and Universities; the Convenor to have power to co-opt.

iii) The representative from each organisation should be a senior person with the necessary technical expertise.

iv) Task Group members should establish mutual trust, pool all relevant information, define the problems and assess the risks.

v) They should recommend common monitoring methods.

vi) They should verify reports, statements, investigations and remedies, etc on resistance to the NZCPR.

vii) They should encourage resistance research and help guide its direction.

viii) They should identify pests and pesticides subject to high risk of resistance.

ix) They should recommend technical strategies aimed at prolonging the useful life of pesticides to the NZCPR.

The Fungicide Task Group comprises M.S. Moore (Convenor) and B.N. Smith of AGCARM, R.E. Beever of DSIR, K.G. Tate and L.H. Cheah of MAFTECH, R.E. Gaunt of Lincoln College and T.M. Stewart of Massey University. Priorities for consideration by the Task Group were proposed, namely dicarboximides, acylalanines, ergosterol biosynthesis inhibitors in apples and cereals, benzimidazoles in cereals, and 
fungicide use in integrated mite control (apples).

The Insecticide Task Group comprises C.H. Wearing (Convenor) and D.M Suckling of DSIR, R. Buchanan, S. Gibb and R.W. Prince of AGCARM, R.B. Chapman of Lincoln College, P.G. Fenemore of Massey University, and A.R. Tomkins and R.H. Blank of MAFTECH. The proposed priorities for this Task Group were mites and miticides, the leafroller complex, aphids and particularly Myzus persicae, greenhouse whitefly (Trialeurodes vaporarium), and diamondback moth (Plutella xylostella). All of these problems are horticultural.

While NZCPR recognised the importance of resistance for household pest control and stored product pests, action on these was deferred. The management of resistance in the field of livestock pests was viewed as presently outside the purview of NZCPR.

\section{CONCLUSIONS}

The potential benefits to New Zealand from instituting pesticide resistance management are manifold. Resistance is a threat to our valuable export horticultural industry which has become dependent on a narrow range of chemicals which have world-wide acceptance in residue tolerances. Moreover, the high and increasing cost of research and development for new pesticides should not be squandered through pesticide usage which disregards resistance risk. If we are to see that these new groups of sophisticated chemicals have extensive use and a long effective life, it is imperative that all sections of the agricultural community give the same message on how best to achieve this. Conflicting advice from different sectors only serves to confuse the end-user and the public. This results in poor implementation of the desired strategies and probably overuse or, at best, incorrect use, of an important chemical group and its ultimate demise.

The NZCPR believes that, with its formation, New Zealand is taking a responsible unified Government/Industry approach to an important problem with the potential to benefit all sectors of agriculture and all consumers, as well as the chemical industry.

\section{ACKNOWLEDGEMENTS}

We thank Drs W.F.T. Hartill and R.E. Beever for their constructive comments on the manuscript.

\section{REFERENCES}

Alcock, K.T. and Drew, M.R., 1986. The Australian agricultural and veterinary chemical industry resistance management policy. In Daly, J. and Suckling, D.M. (Eds) Insecticide Resistance Management. Proceedings of a Joint CSIRO/DSIR Workshop, Canberra, Australia, July 1986, pp. 126-131.

Bollard, E.G., 1981. Prospects for horticulture. A research viewpoint. New Zealand DSIR Discussion Paper No. 6, 212 pp.

Chapman, R.B., 1982. Arthropod pest resistance to insecticides in New Zealand, In Geelen, J.A. and Esson, M.J. (Eds) Proceedings of Pesticide Resistance Seminar, Hawkes Bay Branch of the New Zealand Weed and Pest Control Society Inc., pp. 67-97.

Chapman, R.B., Penman, D.R. and Walker, J.T.S., 1987. European red mite resistance to organotin miticides in Hawke's Bay apple orchards. Proc. 40th N.Z. Weed and Pest Control Conf.: (in press).

Delp, C.J., 1986. Actions and proposed policies for resistance management by agricultural chemical manufacturers. In Pesticide Resistance Management. Strategies and Tactics for Management. National Academy Press, Washington D.C., pp. 388-392.

Delp, C.J. and Dekker, J., 1985. Fungicide resistance: definitions and use of terms. EPPO Bull 15: 333-335.

Daly, J. and Suckling, D.M., (Eds), 1986. Insecticide Resistance Management. Proceedings of a Joint CSIRO/DSIR Workshop, Canberra, Australia, July 1986, $142 \mathrm{pp}$.

EPPO, 1985. Conclusions du Symposium OEPP sur la résistance aux fongicides, 8-9 November 1984. Bull. OEPP-EPPO Bull 15: 331-332. 
Forrester, N.W. and Cahill, M., 1986. Management of insecticide resistance in Heliothis armigera - A critical assessment of results to date. In Daly, J. and Suckling, D.M. (Eds) Insecticide Resistance Management. Proceedings of a Joint CSIRO/DSIR Workshop, Canberra, Australia, July 1986, pp. 89-90.

Geelen, J.A. and Esson, M.J. (Eds), 1982. Proceedings of Pesticide Resistance Seminar, Hawkes Bay Branch of the New Zealand Weed and Pest Control Society, Hastings, $116 \mathrm{pp}$.

Georghiou, G.P., 1986. The magnitude of the resistance problem. In Pesticide Resistance. Strategies and Tactics for Management, National Academy Press, Washington D.C., pp. 14-43.

Hartill, W.F.T., 1986. Resistance of plant pathogens to fungicides in New Zealand. N.Z. J. Exp. Agric. 14: 239-245.

Jackson, G.J., 1987. Learning to "manage" insecticide resistance. Farm Chemicals April 1987: 32-33.

National Academy of Sciences, 1986. Pesticide Resistance. Strategies and Tactics for Management. National Academy Press, Washington D.C., 471 pp.

Suckling, D.M., Wearing, C.H., Thomas, W.P., Penman, D.R., Chapman, R.B., 1984. Insecticide resistance in the lightbrown apple moth: A case for resistance management. Proc. 37th N.Z. Weed and Pest Control Conf.: 248-252.

Thind, T.S., Clerjeau, M., Olivier, J.M., 1986. First observations on resistance in Venturia inaequalis and Guignardia bidwelli to ergosterol-biosynthesis inhibitors in France. Proc. 1986 British Crop Protection Conf. 4C-1: 491.

Wearing, C.H., 1986. Insecticide management policy for New Zealand: a discussion paper. In Daly, J. and Suckling, D.M. (Eds), Insecticide Resistance Management. Proceedings of a Joint CSIRO/DSIR Workshop, Canberra, Australia, July 1986, pp. 110-118.

Wearing, C.H., Walker, J.T.S., Collyer, E. and Thomas, W.P., 1978. Integrated control of apple pests in New Zealand 8. Commercial assessment of an integrated control programme against European red mite using an insecticide-resistant predator. N.Z. J. Zool. 5: 823-837. 